\title{
The Changes of the Symbolic World in Gamelan
}

\author{
Sahid Teguh Widodo \\ sahidteguhwidodo@yahoo.com \\ Universitas Sebelas Maret
}

\author{
Agus Purwantoro \\ goespoer13@staff.uns.ac.id \\ Universitas Sebelas Maret
}

\begin{abstract}
Until now, traditional Javanese musicians are still looking for forms and reasons for the changes that occur in Javanese gamelan music. Some people blame technology that is always positioned as a source of change. Technology is a source of changes in people's cultural tastes so that the views and needs of society towards gamelan also change. Some people see that changes as development. They are not very concerned with the form but emphasize the existence of gamelan. This short paper seeks to reveal the meaning of all aspects of change by looking at the symbolic meaning among what is considered to exist.
\end{abstract}

Keywords: Gamelan, Javanese, symbolic changes, cultural tastes.

\section{BACKGROUND}

In the simplest area, gamelan is understood as a set of traditional musical instruments played by several people by tinabuh 'beating' (Jazuli, 2010). A simple definition like this actually comes from the education perspective that always defines objects by relying on the power of the senses. Understandings or perspectives that are extreme different may come from people who are culturally religious and Javanese traditional artists. They stated that gamelan is life. Gamelan is the spirit of Javanese cultural life. Gamelan is the culmination of Javanese culture. On the other hand, cultural studies look at it as cynical "logocentrism", and uncover the constructs of meaning that have been "established" in various circles by making new interpretations that are strongly influenced by Western thoughts with deconstruction model, commodification, hegemony, etc (Harjana, 2007). that see object from power relation.

Exciting. That is the general impression on gamelan conversation when the symptoms of resonance are increasingly felt and already have a place in all parts of the world (see Supanggah, 2002). Interestingly, each cultural locus has a different response to gamelan life from time to time. Gamelan is often associated with the development of Western music. Even in the part of gamelan community, emerges the view that gamelan is Eastern art of the West minus. That is, the value and existence of gamelan is always measured in terms of Western "mechanical" methodology. Unfortunately, the criticism of these critical voices was voiced using Western theoretical bases as well so that it was difficult to find the good results. On the contrary, experts from this cultural study group are often trapped in post-colonial theories that are always captivated by the relation of phenomena with power Sunarjo, 2001).

On the other hand, critical methods lack the courage to capture aspects of gamelan spirituality (Yudoyono, 1984). In the fact that is the core of substantial existence from the Javanese Gamelan. The second mistake seen that critical studies today are not able to find gaps clear because it is constantly entangled by theoreticalconceptual charm. As a result, often cultural studies reviews are only able to touch surface structure. The rest is the impression of unrest caused by not fully understood the basic conception of cultural studies from the methodological aspects.

PARADIGMATIC CRISIS OF GAMELAN

Many people have thought that today the gamelan is very less attractive to the Javanese people. Even a comment appears, "Javanese 
gamelan is at the intersection". They added, Javanese gamelan was trapped in a mediocrity situation. Want to reach modernity, not enough courage and be blocked by the conventionalist group (Karl, 2004). Meanwhile, wanting to return to tradition is blocked by new cultural tastes originating from modern arts. Although still giving room to choice, the Javanese gamelan was gradually feared losing its grip and entering into a difficult situation (in the era of young people) and in the end failed to find its own spirit.

The crisis that occurred in gamelan life was actually a paradigmatic crisis. The paradigmatic crisis of gamelan occurs in our perspective on gamelan, the gamelan's living environment, and how it affects our way of thinking about it. Crisis Paradigmatic gamelan occurs in slices of three interconnected forms, namely: world view/ weltanchauung, traditional assumptions, and practices (Soedarsono, 2002).

Understanding this world view is important to know better what is the role and activity, community response and participation in gamelan life? This actually concerns the life of the Javanese people themselves. Yudoyono (1984) explain that regarding the spirit in a lives of the people themselves in all fields. Even regarding the values, institutions, values, ideals, dreams, and ideologies of life that are built in them. Javanese society has grown and developed naturally, organized and maintained its own values which tended to experience a reasonable "life process".

Understanding this world view is important to know better what is the role and activity, community response and participation in gamelan life? This actually concerns the life of the Javanese people themselves. Regarding the spirit in a lives of the people themselves in all fields. Even regarding the values, institutions, values, ideals, dreams, and ideologies of life that are built in them. Javanese society has grown and developed naturally, organized and maintained its own values which tended to experience a reasonable "life process".

Today's public assumptions are more influenced by the empirical experience that gamelan (especially in Solo and its surroundings) is still regarded as a potential medium of communication among various forms of modern art products. Gamelan is a

traditional art that is still able to attract stakeholders among the young and old. For young groups (Herawati \& Mardowo, 2017), they certainly crave newness of form (form) rather than as a nostalgia for the past like the elderly.

Gamelan practices increasingly show the myth of new liberation. The younger artists tend to want to loook for a new elements in gamelan. A set of modern musical instruments such as bongo, saxophone, guitar, etc. stuffed in to fill the remaining spaces. Today's tradition has changed compared to 50 years ago.

The paradigmatic crisis that now occurs in Javanese gamelan cannot be separated from the inner corner of Java. If that is allowed to happen, the Javanese people - and the international collective who feel that they have ownership - are in the position of the condemned subject on passivity, and not a subject who has a full force. the paradigmatic crisis must be overcome immediately, although Javanese inner liberation does not necessarily occur, but leaves residues in the form of stunted and fragile feelings, fragility of the bones of life, and power blockages which result in paralysis of the system in the world of life. Let's keep thinking.

\section{BASIC VALUE OF GAMELAN}

Gamelan lives and develops, while at the same time survives, in the midst of the Javanese nature that gemah ripah loh jinawi 'very rich, fertile and beautiful' (Sastrowardoyo, 1977). Gamelan complements the needs of its harmonious community and has a strong spiritual culture. Gendhing in the gamelan accompaniment describes the characteristics of Javanese spiritual culture, inner behavior related to human understanding of the nature of life. That is, life that has a definite purpose, "manembah" and "memayu hayuning jagad raya" beautifies the beauty of nature in its entirety " (Supriatna \& Sutanto, 2010). So it is not surprising that the gamelan can then live alongside other forms of Javanese culture. The 
gamelan tradition seems to be able to become the basis in the universe, humans live together and side by side become very easy and peaceful with other elements of life.

Starting from that explanation, the gamelan turned out to have links with the basic material of Javanese life and life in general. Gamelan can be used by all people (space and time). In other words, the basic value of gamelan applies to all elements and all elements of human life, the universe, and the whole universe.

Gamelan has three basic values in the life of Javanese society, namely:

1) Divine value, gamelan is a tool that can deliver humans to the peak of their servitude to God. Gamelan is a marker of humorous spirituality, a life full of harmony, mutual cooperation 'collaboration', tepa slira 'full understanding', etc. Gamelan has a different character, character and authority in how to explain it compared to orchestral music or modern Western symphonies. Even though each of them has their own majesty. Gamelan is an instrument that shows how humans know God, know and live with other creatures, know and live together with "something" that is not visible to the eye. Gamelan is a Javanese moral and spirit wisdom

2) The value of universality, gamelan is a way for humans to gain complete knowledge of life from the beginning of life until the end of death, to then live and come back to life, united with God (united with Gusti). Gamelan is the culmination of the expression of human beauty and gratitude for the universe. Overall means complete, complete, unity between instrument elements in it (Kendhang, Bonang, Bonang Penerus, Rebab, Kenong, Kethuk, Kempul, siter, demung, peking, and Slenthem). Obviously, Gamelan in the end is a selling process that always seeks to understand the nature of the surroundings. This inner practice of universality allows humans to capture the sasmita and landmark of nature, as the peak of this inner practice. We often forget about this natural language, so that we do things that hurt, even destroy nature.

3) Value of Civilization, the existence of gamelan guarantees the continuity of Javanese civilization. Java is guaranteed to never be lost if the gamelan is still heard, played, and developed in the middle of the human life of its owner. Gamelan is also a role model for other matching arts. Finally, it can be concluded, that gamelan can encourage people to achieve the highest degree by way of sticking to the law of life, seeking life knowledge (wirya, Arta, Winasis, Serat Wedhatama) and mind (the level of worship and morals: nistha, madya, main).

\section{GAMELAN: THE CHANGES OF THE GLOBAL SYMBOL}

Every decade of time turns out to produce unique and distinctive symbols. These symbols are produced by Javanese people or others as a migrant culture which strongly influences / colors Javanese culture. Changes in the symbolic universe can be known from (1) the age category, namely certain circumstances (phenomena) that can show what is going on. (2) existing social institutions and have a dominant role, (3) symbols produced in each period of time, (4) norms, rules that are mutually agreed upon, understood, and regulated (intentionally enforced) in the private and collective domain. Every decade of time turns out to produce unique and distinctive symbols. These symbols are produced by Javanese people or others as a migrant culture which strongly influences/colors Javanese culture (see Harjana, 2007; Supanggah, 2002). Changes in the symbolic universe can be known from (1) the age category, namely certain circumstances (phenomena) that can show what is going on. (2) existing social institutions and have a dominant role, (3) symbols produced in each period of time, (4) norms, rules that are mutually agreed upon, understood, and regulated (intentionally enforced) in the private and collective domain.

In the category of traditional patrimonial Javanese society, the dominant social 
institution is the kingdom (raja-abdi dalem), the prevailing symbol is mythic. The king is believed to be a representative of God. The word pandhita queen 'the voice of the king is the voice of God' so that the position of the king is very high. Whereas the prevailing norm is the norm of compliance. Gamelan becomes one of the tools of power to anchor the symbols of power. The Gamelan comes with great myths that confirm the position of the king as an absolute ruler. Gedhe songs become "bridges" of monarchs who control life. The sekaten gamelan seems to be a single thruth that controls people's creativity, taste, intention and behavior. Gamelan becomes the rhythm of people's lives Over time, time went into the capitalist gates and investors began to set up private factories. Farmers began to move mobilized by mass labor needs. The atmosphere of the village and village quickly changed following the rhythm of working hours. Gamelan experiences a shift in form, function and meaning. Gamelan is no longer the only source of community entertainment. But there is a shift of function as the art of priyayi clan, middle class, and the general public in its own circle of meaning. However, it still captivates the hearts of most people. The mythic symbol has turned into a realist.

Entering the next category is the technocratic era. The power of the kingdom has changed into a concept of the state that takes a lot of roles to reduce the dominance of the private sector. All moving elements (privatestate). This creates an atmosphere of uncertainty so that the symbols formed are pseudo-realist. Gamelan remains a major work of Javanese ancestors, and for him all agreed to preserve it. But the reality is poor action. Gamelan has come out of the grip as a pseudorealist symbol statement 'as if'. In fact, the triangular gamelan becomes a collective Javanese symbolic narrative and no longer as an object that gives color. Javanese people "as if they still have, angry if taken from him, but in the least there is no positive action in favor of the gamelan (Soedarsono, 2002).

Next is the Digital category. Gamelan enters an invisible cultural realm. The role of humans as producers of culture has really been taken over by digital technology. Gamelan teaching is carried out in bulk through internet, skype, twitter, youtube, facebook, etc. Even the desire to digitize gamelan grew by using a gadjet that had been programmed in such a way that the results of the sound were quite good. Something is missing from the news of this progress. It is, human interaction that actually becomes the spirit (life force) of sound, meaning and philosophical meaning of gamelan. In the context of a student who learns from a gamelan teacher / gamelan teacher, there is an empirical knowledge that is difficult to explain. Learning gamelan in a nyantric way will certainly take a very complicated natural procedure because not only honing your playing skills, but also sharpens your awareness, memory, sensitivity and feeling the subconscious!

The development of gamelan running roams towards the virtual sybernetic category, which is the supercompetitive era of cyberspace. Described that the human sky is no longer a painting of stars, mega-mega, and / or moon and sun. However, the cluster of information is increasingly complete and adequate, leaving the old life to a sophisticated life that connects every element of life without space or time. Gamelan games in the European hemisphere, Australia, Africa, and especially Asia are growing. Groups, art studios, or clubs are increasingly interested in the younger generation. The world of gamelan is the pinnacle of the exciting world of creativity in the past, full of challenging adventures, etc. When compared to the past, clearly there have been many changes. In fact, it might only be tracked as a document.

\section{THE FUTURE OF GAMELAN}

Gamelan is an old heritage that still shows the charm of a very high civilization culture Yudoyono, 1984). Gamelan is in demand as a chapter of life that continues to radiate value among almost perfect modern values. Gamelan provides alternative meaning and deepening of knowledge that has never been completed, and instead continues to evolve into the work of the world. 
Of course the problem can come along with symptoms of changes in the symbol of the universe that are constantly being processed. The solution lies in the way we find local responses to global symptoms with the form of magic, preservation. Conservation is the process of managing traditional art through protection, development and utilization. Protect from regulatory aspects, funding, facilities, human resources, etc. Development through creative touch from the same aspect. And Utilization in a mental context, identity and generating income.

The future of the gamelan is a good condition and a destination in the future. Of course we all hope that gamelan can still exist, grow, and develop beyond a very long period of time. Gamelan will be able to keep abreast of developments if the owners, connoisseurs, and devotees also have qualities that are open to various things that occur in the development of life and life of gamelan. Traditional Gamelan is the parent of modern gamelan mining.

Of course we still have to talk and discuss again. Hopefully.

\section{REFERENCES:}

Hardjana, S. (2003). Corat-Coret Musik Kontemporer Dulu dan Kini. Jakarta: Ford Foundation dan Masyarakat Seni Pertunjukan Indonesia.

Yudoyono, B. (1984). Gamelan Jawa Awal Mula Makna Masa Depannya. Jakarta: PT Karya Unipress

Herawati, N. \& Mardowo, S. (2017). Gamelan. Klaten: PT Intan Pariwara.

Sastrowardoyo. (1977). Gendhing-Gendhing Pakurmatan. Surakarta: PKJT.

Jazuli, M. (2010). Paradigma Seni Pertunjukan. Yogyakarta: Yayasan Lentera Budaya.

Karl-Edmund, P.Sj. (2004). Ilmu Bentuk Musik. Yogyakarta: Pusat Musik Liturgy

Sedjawati, E. (1981). Petumbuhan Seni Pertunjukan. Jakarta: Sinar Harapan

Soedarsono.(2002). Seni pertunjukan Indonesia di era globalisasi. Yogyakarta: Gadjah Mada University Press.

Sumardjo, J. (2001). Seni Pertunjukan Indonesia. Bandung: STSI Press Bandung.

Supanggah, R. (2002) Bothekan Karawitan I. Bandung: MSPI

Supriatna \& Sutanto. (2010). Belajar Menabuh Gamelan Salendro. Bandung: Bintang

WarliArtika 